Agriculture, Agribusiness and Biotechnology

Vol.60: e17160370, January-December 2017 http://dx.doi.org/10.1590/1678-4324-2017160370 ISSN 1678-4324 Online Edition

AN INTERNATIONAL JOURNAL

\title{
Functional Genes of Microorganisms, Comprehending the Dynamics of Agricultural Ecosystems
}

\author{
Catiusca Reali $^{1 *}$, Harry Luiz Pilz Júnior ${ }^{1}$, Jean Christophe Meile ${ }^{2}$, Sabine Shorr Galindo ${ }^{3}$, \\ Lidia Mariana Fiuza 4 . \\ ${ }^{I}$ Universidade do Vale do Rio dos Sinos - Laboratório de Microbiologia e Toxicologia, São Leopoldo, Rio Grande \\ do Sul, Brasil; ${ }^{2} \mathrm{CIRAD}$ - Qualisud, Montpellier, France; ${ }^{3}$ Université de Montpellier, Montpellier, Languedoc- \\ Roussillon, France; ${ }^{4}$ Instituto Rio Grandense do Arroz, Cachoeirinha, Rio Grande do Sul, Brasil.
}

\begin{abstract}
The microbial composition of different types, in ecosystems (including agro-ecosystems), has been investigated in a rapidly growing number of studies in the past few years. The importance of microorganisms, regarding the maintenance and stability of nutrients in agroecosystems, is a key to maintain the sustainability of a crop. Molecular tools to study microbial communities are possible through many methods such as RISA, DGGE, TGGE, clone libraries, T-RFLP, RAPD, SSCP and more recently NGS (Next-Generation Sequencing). DGGE is widely employed to characterize the diversity and the community dynamics of microorganisms in the environment, making possible to find out specific groups through functional genes, allowing access to data that cannot be obtained by cultural methods. The aim of this paper is to review the functional groups related to agroecosystems and to indicate the critical choice of DNA primers pairs and targeted DNA regions that may be used in PCR-based methods such as the $D G G E$ technique in order to evaluate the microbial communities in a variety of environments.
\end{abstract}

Keywords: agroecosystems, functional genes, bacteria, DGGE, metagenomics, microbial ecology

\footnotetext{
*Author for correspondence: catiuscar@gmail.com
} 


\section{INTRODUCTION}

Microorganisms play a major role in biochemical cycles, soil and water nutrient reposition, and they could be used as biological indicators of soil quality ${ }^{1}$. Molecular biology tools have become important to allow the identification of key species in ecosystems ${ }^{2}$, or even for the identification of microbial communities with specific functions. The functions realized by the microorganisms can be related to: the fixation of atmospheric nitrogen, decomposers of organic residues or pesticides residues, promote the cycling of nutrients, fight diseases in plants caused by pathogens present in the soil and produce bioactive compounds like vitamins, hormones and enzymes that stimulate the growing of the plants ${ }^{3}$.

As most bacterial species present in general ecosystems cannot be grown in laboratory conditions, the use of culture-independent, PCR-based techniques is very promising to explore microbial communities ${ }^{4,5}$. For example, the PCR-DGGE technique, besides from inferring communities that are present in soil and water, may also help to identify epiphytic ${ }^{6}$ and endophytic bacterial communities ${ }^{7,8}$, which are relevant in agroecosystems studies.

Agroecosystems provide different environments with a wide variety of microhabitats. Rice fields, for instance, remain irrigated during most of the culture cycle $^{9}$, and may have a quite complex bacterial community ${ }^{10}$. Culture management and farming systems also interfere with microorganisms composition. Crops in general are manipulated during the agricultural year receiving the addition of different nutritional inputs, besides irrigation and soil trundling, for instance. Moreover, the phenological phases of crops may also modify soil characteristics through the excretion or absorption of substances by plants ${ }^{11,12}$.

Microorganisms, for many reasons, directly affect crop development. Microbiota in the soil and water provide nutrient cycling in rice paddy ecosystems ${ }^{13}$. The study of bacterial functional groups allows the identification of specific activities in these environments related to nutrient availability and methane consumption, which is a key function to decrease greenhouse gases production ${ }^{14-16}$.

Ecological studies about bacterial functional groups present in the water and soil of dry or irrigated agroecosystems, allying techniques that are culture-independent or dependent through selective media may bring important data regarding the nutritional dynamics in these environments.

\section{Microorganisms and the functionality of ecosystems}

The functional diversity comprehends a wide range of microbial activities in the environment, assuming great importance in ecology studies ${ }^{17}$, considered an important characteristic in biological assemblages ${ }^{18}$, it supports many services to the ecosystem ${ }^{19}$. Species cannot provide the same effect above the ecosystem functioning, they can participate in different process ${ }^{20}$, in other words, a variation on the microbial composition can represent a variation in the services provide by biological communities. Nevertheless, very little is known about the relationship between structural and functional diversities.

Authors have quoted some theories about the effect of species diversity regarding particular functions in the ecosystem. Some of them suggest that ahigher species diversity is beneficial to the functionality of ecosystems ${ }^{21,22}$. Relate the stability of ecosystems to species diversity, since they have fast growth and may occupy vague niches rapidly, may afford an efficient environment recovery after perturbation, or in other words, it returns to equilibrium condition very fast ${ }^{17,22,23}$. On the other hand, some authors claim that functionality relies more in species composition, therefore, in the ability of certain species to exert functions in ecosystems ${ }^{24-26}$. 
Over the past 50 years several studies has been trying to clarify questions about the diversity of species in relation to ecosystem functions ${ }^{27-30}$. This type of study is very used to communities of plants and animals ${ }^{31}$. However, for bacterial communities, it was only possible after the introduction of molecular biology methods, this happens due the difficulty imposed by conventional techniques in getting enough data for obtaining the diversity ${ }^{27,32,33}$. More information about methods used to obtain data through techniques for microbial ecology studies are described below.

The high functional divergence can be associated with a high degree of differentiation niches ${ }^{20}$ and less competition for resources ${ }^{18}$. For species adapt well to a location, they need to tolerate the abiotic characteristics, species adapted to the same local tend to have similar functional characteristics ${ }^{34}$, however,many species ecologically similar could not happen in a single place ${ }^{24}$, thus, the competition can act producing functional divergence within communities.

Bacteria have a long evolutionary history, they are able to colonize the most varied environments, occupying many niches ${ }^{35}$. Nevertheless, the constant management in agricultural ecosystems may cause changes in the species composition caused by placing the rice straw on the soil ${ }^{36}$, application of pesticides ${ }^{37-39}$ or increase, in some species, benefit from exudates of plants. ${ }^{40,41}$. The management, in general, can benefit populations of most species adapted to the environment through the detriment of others, causing a decrease in species diversity, however, may benefit certain functional groups.

The reduction of species not always represent a loss in functions in the ecosystem, functional redundancy may occur or several species are capable of performing the same function ${ }^{42}$. However, despite carrying the same function, they cannot have the same efficiency, produce different metabolites as an end product or even may have lower growth rates and are not be competitive as the original community ${ }^{27}$. The exclusion of some species can influence the composition of other populations as a result, it causes changes in other global ecosystem functions, despite having kept the original function ${ }^{43}$.

\section{Techniques for the Identification of Functional Groups}

Conventional techniques only provide partial data about diversity and functionality in ecosystems since they select groups that develop better in culture media and laboratory conditions. However, when they are allied to molecular biology techniques the results become more satisfying.

In order to access the diversity of species or functional groups through molecular techniques, a total DNA extraction must be performed from samples such as soil, water, sediments or even plants in the case of endophytic bacteria. Total DNA content is representative of the bacterial populations present in the environmental sample ${ }^{44-46}$. The advantage of using culture-independent techniques is that they do not present a series of methodological barriers to the growth and multiplication of the group to be approached, since they can be withdrawn directly from their natural habitat, from which total DNA may be extracted ${ }^{47}$. Studies indicate that around $99 \%$ of microorganisms present in the environment cannot be grown in the laboratory ${ }^{48}$. As for the bacterial diversity, many functional groups may be accessed by cultureindependent techniques ${ }^{32,33,49}$. This sort of study facilitates the recognition of bacterial in specific environments, including agroecosystems ${ }^{50}$. Therefore, communities may be evaluated through time or even after disturbance simulations.

Several culture-independent techniques are utilized to obtain a profile of microbial communities: Ribosomal Intergenic Spacer Analysis - RISA ${ }^{51}$, Denaturant Gel Gradient Electrophoresis - DGGE ${ }^{52}$. Temperature Gradient Gel Electrophoresis TGGE $^{53}$, clone libraries ${ }^{54,55}$, Terminal-Restriction Fragment Length Polymorphism 
- T-RFLP ${ }^{56-58}$, Random Amplified Polymorphic DNA - RAPD ${ }^{59}$, Single-Strand Conformation Polymorphism - SSCP ${ }^{60}$ and Next-Generation Sequencing - NGS ${ }^{61}$.

Studies performed with bacteria in freshwater ecosystems are basically concerned with phylogenetic aspects, using sequence analyses of the 16S rRNA gene polymorphisms and related techniques ${ }^{32}$. However, functional diversity has been studied by methods based on specific enzymatic activities. The use of functional genes brings a whole new perspective which is to access the microbial ecology. One of the main advantages in the use of functional genes is the possibility to restrict the study to the target functional group, indicating the phylogenetic relatedness of the carrying bacterium but gives few clues about its physiology ${ }^{62}$.

Among the cultivation-independent methods, the fingerprinting is one of the most common techniques. Through them, it is possible to access the most abundant members of the microbial communities quickly, not involving high costs. DGGE is a technique widely employed to characterize microbial diversity and community dynamics in the environment, with the possibility to access specific groups through functional genes ${ }^{63-66}$. DGGE with amplification of PCR fragments from the $16 \mathrm{~S}$ $r D N A$ gene was first employed by ${ }^{52}$ to access biofilm-forming bacteria, but today it is used to access several functional groups in a variety of environments.

DGGE application is possible through total DNA extraction from environmental samples, that is, the mixture of bacterial communities present in those samples. The species present in the sample are separated through the denaturing gradient of a DGGE gel. The number of bands in the pattern corresponds to the number of predominant members in the community ${ }^{53}$. The band patterns are formed by the base pair sequences, not according to the DNA fragments size, which allow separation of species or bacterial species groups.

A variation of this technique is TGGE, which uses a thermal gradient to separate the groups maintaining constant urea and formamide concentrations.Band patterns can be evaluated by different softwares that normalize data and calculate abundance and richness of species through thickness and number of bands. Each band position is registered in a database where the comparison between DGGE gels is performed, but they must have the same denaturation gradient and migration time, that is, the gels must have a standardized methodology ${ }^{67}$.

Species of communities are identified by band excision from the gel followed by sequencing or hybridization with specific DNA probes. Genes such as 16SrRNA (around 1,500 nucleotides) serve as clone libraries associated to many bacteria groups in a variety of environments. Soil and sediment alone comprise around 10,000 different bacterial species ${ }^{68}$. However, the necessity of more punctual studies led to the use of functional genes, which restrict the approach to the target group only, and not the whole environmental diversity.

Still, it is possible tocompare microbial populations or communities by next generation sequencing ${ }^{69}$. Moreover, sample sequencing costs tend to decrease through the application of new sequencing technologies, which are more efficient, and with higher competition between companies that provide such services ${ }^{70}$.

Next-Generation Sequencing (NGS) methods, such as pyrosequencing, Ion Torrent, Illumina and SOLiD Systems, bring a large-scale information about the diversity of microorganisms, starting a new path in microbial ecology ${ }^{71}$. The challenge today is how to interpret that amount of results and information generated by these new technologies ${ }^{70}$. NGS methods has the advantage of generating, in a few hours, megabase sequences ${ }^{72}$, and can be used to describe bacterial communities in various environments ${ }^{35}$. Pyrosequencing works through fluorescence detection, but also have some limitations. They are related to the sequencing of homopolymeric stretches, which may define the insertion or deletion of nucleotides by the intensity of the light signal, changing the results ${ }^{73}$. Some algorithms were designed to correct 
this problem ${ }^{74,75}$. Ion Torrent ${ }^{76}$ and Illumina ${ }^{73}$ are the both "benchtop" sequencers most widely sold and has a relatively low cost; they use highly informative fractions of 16S rRNA gene ${ }^{77}$. Most sequencers using bases labeled with fluorophores, in the Ion Torrent the polymerase reaction generates a proton, modifying the $\mathrm{pH}$ of the medium. This $\mathrm{pH}$ change is detected by a transmitter and converted into an electrical signal.

Directing the study for the microorganisms who had roles in the ecosystem, GeoChip, developed amicroarray method ${ }^{78}$, containing more than 24,000 probes and covers, 150 gene families involved in biogeochemical C, N and P cycling ${ }^{79}$ an important tool in agricultural ecosystems. NGS use a more robust analysis and as a consequence, increase the analytical power of results, being more important in several projects involving genomics and metagenomics ${ }^{70}$. Bioinformatics software are fast and are in steady development, increasing the amount of data evaluated and contributing to the construction of megabases, increasing, as well, the amount of information on various ecosystems.

\section{Functional genes}

In agricultural environments many microbial activities are related to plant development and consequently to crop productivity. Functional biodiversity in agroecosystems is an ecological key to sustainable production, and microorganisms have a fundamental importance in this process ${ }^{2,80}$. Soils that are poor in microorganisms exhibit a higher demand on fertilizers and synthetic addiction of nutrients, which besides increasing production cost, may also increase the risk of contamination of nearby natural environments. Moreover, some nutrients rely on microorganisms to be absorbed such as mycorrhizal bacteria and fungi which are directly associated to nutrient absorption by plants.

Microbial characterization of specific environments such as agro-ecosystem soils or water from irrigated crops may be performed with the use of different target genes. Describing the microbiota of these sites brings a series of new insights into the functional roles of fungi and bacteria in those habitats. Among the functional groups present in the soil,with particular agricultural importance, are microorganisms such as diazotrophic, denitrifying and ammonifying bacteria. As well microorganisms capable of degrading complex polymers, methanogenic and methanotrophic bacteria and archaea participating in the carbon cycle. An overview of functional groups discussed in this paper can be found in Table 1.

The use of specific DNA primers to detect the related genes brings a rapid response regarding the presence and composition of functional groups. Today there are a few sets of oligonucleotides, which are used according to the group to be accessed (Table 2). A genetic region that is sufficiently conserved among the target group allows the design of primers used to the identification of such groups, but this does not mean this functional gene is actually being expressed by the community in the environment ${ }^{50}$.

The urea is the principal nitrogen fertilizer utilized in rice crops, however occurs a great loss of nitrogen by the volatilization in ammonia $\left(\mathrm{NH}_{3}\right)^{105}$. The loss of nitrogen fertilizers in crops may be $20-40 \%$ of the nitrogen applied ${ }^{106}$. Ammonia oxidation is the key step in the nitrogen cycle ${ }^{86,107}$ were the enzyme ammonia monooxygenase (AMO) oxidizes ammoniac to hydroxylamine and is encoded by $a m o A$ and $a m o B$ genes ${ }^{108}$. The functional group of ammonia-oxidizing bacteria can be accessed through the amoA-1F e amoA-2R primers $2 \mathrm{R}$, describe by ${ }^{99}$. Hydroxylamine oxidoreductase (HAO) oxidizes hydroxylamine to nitrite ${ }^{109}$ and is composed of subunits encoded by the hao gene ${ }^{110-112}$. 
A problem, resulting from the water of crops, is the production of methane, produced by aerobic bacteria ${ }^{62,113}$. In anaerobic environments, as flooded soil of crops, anaerobic bacteria ${ }^{114,115}$ or archaeas ${ }^{116}$ transform methane in nitrite, nitrate, sulfate and metal ${ }^{83}$. The pMMO enzyme is universally found in methanotrophic bacteria and is therefore used as a functional marker for these organisms ${ }^{97,82,117}$. The $p m o A$ gene has been used as a marker for methanotrophic bacteria ${ }^{14}$ and encodes a subunit of methane monooxygenase enzyme ${ }^{118}$. A189 and A682 primers are frequently used to profile communities that oxidize methane in the environment ${ }^{119-121}$. Moreover, other studies also bring the reverse primer mb661 and A650 with detection sensitivity for the pmoA gene ${ }^{96}$. However, the use of the A189 and A682 is limited to environments with high frequency of methanotrophic bacteria. The A189 and A650 primer set may not target all genus of methanotrophic bacteria but can bring satisfying results regarding community composition ${ }^{97}$. According to the same authors the A189 and mb661 primer set exhibited the highest number of genus and highest bacterial diversity of the pmoA gene. Nevertheless, the use of the three sets may be necessary in order to obtain the more complete composition.

The rhizosphere bacterial community may be accessed through the nifH gene. Diazotrophic bacteria promote nitrogen biological fixation through a highly conserved enzyme called nitrogenase ${ }^{88,89}$. The nifH gene is considered as a good marker for heterotrophic bacteria ${ }^{122}$, although there are many others that are also employed such as nifD and nifK ${ }^{123}$. The nirK and nirS genes participate in the nitrogen cycle through denitrification with the action of the nitrite reductase enzyme ${ }^{65,90,91}$, and so does the nos $Z$ gene through the nitrous oxide reductase enzyme ${ }^{92}$. 
Table 1. Descriptions of functional groups and your attributions in agroecosystems.

\section{Functional group Description}

Aerobic methanotrophic bacteria

Aerobic bacteria use methane as carbon source and

energy through the action of the methane

monooxygenase enzyme that oxidizes methane

producing methanol and generating two molecules of

water.

Methanotrophic Archaea

Ammonifying bacteria

Nitrogen-fixing bacteria

Denitrifying bacteria
Transform methane in nitrite, nitrate, sulfate or metal

First step of ammonia oxidation in nitrate, via nitrite. It occurs by the oxidation of ammonia to hydroxylamine, catalyzed by the ammonia monooxygenase enzyme.

Microorganisms make a enzymatic conversion of gaseous nitrogen to ammonia through a highly conserved enzyme called nitrogenase.

Denitrification process through the action of the nitrite reductase enzyme or oxide reductase enzyme.
Agricultural importance

Reference

Aerobic oxidation of methane in aquatic environments

$(81,82)$

such as rice fields. Participate in the carbon cycle.

Reduce the emission of methane gas to the

environment.

Methane oxidation in strictly anoxic environments.

Participate in carbon cycling. They are present in deeper

layers of soil in rice crops because the soil layers

covered by water create an anaerobic environment.

Reduce the emission of methane gas into the

atmosphere.

Fundamental process in nitrogen cycling.

Promote the biological nitrogen fixation, reducing the use of nitrogenous fertilizers.

Assist in biological nitrogen fixation, promoting growth in plants. 
Table 2. DGGE employment in several environments using the following genes of functional groups: $16 \operatorname{SrRNA}, \mathrm{pmoA}, \mathrm{mmoX}$, amoA, nifH, nirK, nirS and nosZ.

\begin{tabular}{|c|c|c|c|c|c|c|c|}
\hline Groups & Gene & Primers & Sequence $\left(5^{\prime}-3^{\prime}\right)$ & $\begin{array}{c}\text { Annealing } \\
\text { conditions } \\
\left({ }^{\circ} \mathrm{C}\right)\end{array}$ & Amplicon lenght (bp) & $\begin{array}{c}\text { Denaturing gradient } \\
\text { and polyacrylamide } \\
\text { concentration }\end{array}$ & Reference \\
\hline \multirow{4}{*}{ Bacteria } & \multirow{4}{*}{ 16S rRNA } & $\begin{array}{c}968 \mathrm{f} \\
1401 \mathrm{r}\end{array}$ & $\begin{array}{l}\text { AAC GCG AAG AAC CTT AC } \\
\text { CGG TGT GTA CAA GAC CC }\end{array}$ & 53 & 434 & $\begin{array}{c}40-80,6 \% \\
\text { polyacrylamide }\end{array}$ & $\begin{array}{l}(93) \\
(93)\end{array}$ \\
\hline & & $\begin{array}{c}63 \mathrm{~F} \\
338 \mathrm{R}\end{array}$ & $\begin{array}{c}\text { CAGGCCTAACACATGCAAGTC } \\
\text { GCTGCCTCCCGTAGGAGT }\end{array}$ & 57 & 489 & $\begin{array}{l}\text { 30-40/60-80, } 8 \% \\
\text { polycrylamide }\end{array}$ & $\begin{array}{l}(94) \\
(94) \\
\end{array}$ \\
\hline & & $\begin{array}{c}357 \\
907 \mathrm{rM} \\
\end{array}$ & $\begin{array}{c}\text { CCTACGGGAGGCAGCAG } \\
\text { CCGTCAATTCMTTTGAGTTT }\end{array}$ & 55 & 586 & $\begin{array}{c}40-80 \%, 6 \% \\
\text { polyacrilamide }\end{array}$ & $\begin{array}{l}(53) \\
(53) \\
\end{array}$ \\
\hline & & $\begin{aligned} 341 \mathrm{f} \\
518 \mathrm{R}\end{aligned}$ & $\begin{array}{c}\text { CCTACGGGAGGCAGCAG } \\
\text { ATTACCGCGGCTGCTGG }\end{array}$ & 55 & 194 & $\begin{array}{l}15-30 / 60-708 \% \text { or } \\
10 \% \text { polycrylamide }\end{array}$ & $\begin{array}{l}(53) \\
(53)\end{array}$ \\
\hline $\begin{array}{l}\text { Aerobic } \\
\text { methanotrophic } \\
\text { bacteria }\end{array}$ & pmoA & $\begin{array}{c}\text { A189f } \\
\text { A682r } \\
\text { mb661r } \\
\text { A650r }\end{array}$ & $\begin{array}{c}\text { GGN GAC TGG GAC TTC TGG } \\
\text { GAA SGC NAG AAG AAS GC } \\
\text { CCG GMG CAA CTG CYT TAC C } \\
\text { ACG TCC TTA CCG AAG GT } \\
\end{array}$ & 56 & 525 & $\begin{array}{l}35-80 \%, 6,5 \% \\
\text { polyacrilamide }\end{array}$ & $\begin{array}{l}(95) \\
(95) \\
(96) \\
(97)\end{array}$ \\
\hline $\begin{array}{l}\text { Methanotrophic } \\
\text { Archaea }\end{array}$ & $m m o X$ & $\begin{array}{l}206 \mathrm{f} \\
886 \mathrm{r}\end{array}$ & $\begin{array}{l}\text { ATCGCBAARGAATAYGCSCG } \\
\text { ACCCANGGCTCGACYTTGAA }\end{array}$ & 60 & 720 & $\begin{array}{c}40-70 \%, 8 \% \\
\text { polyacrylamide }\end{array}$ & $\begin{array}{l}(98) \\
(98)\end{array}$ \\
\hline $\begin{array}{c}\text { Ammonifying } \\
\text { bacteria }\end{array}$ & amoA & $\begin{array}{l}\mathrm{a} m o A-1 \mathrm{~F} \\
\mathrm{a} m o A-2 \mathrm{R}\end{array}$ & $\begin{array}{c}\text { GGGGTTTCTACTGGTGGT } \\
\text { CCCCTCKGSAAAGCCTTCTTC } \\
\end{array}$ & 55 & 491 & $\begin{array}{c}40-70 \%, 8 \% \\
\text { polyacrylamide }\end{array}$ & $\begin{array}{l}(99) \\
(99) \\
\end{array}$ \\
\hline $\begin{array}{l}\text { Nitrogen-fixing } \\
\text { bacteria }\end{array}$ & NifH & $\begin{array}{l}\text { FGPH19 } \\
\text { PolR } \\
\text { PolF } \\
\text { AQER }\end{array}$ & $\begin{array}{c}\text { TAC GGC AAR GGT GGN ATH G } \\
\text { ATS GCC ATC ATY TCR CCG GA } \\
\text { GAC GAT GTA GAT YTC CTG } \\
\text { TGC GAY CCS AAR GCB GAC TC }\end{array}$ & 55 & 452 & $\begin{array}{l}20-70 \%, 8 \% \\
\text { polyacrylamide }\end{array}$ & $\begin{array}{l}(100) \\
(101) \\
(101) \\
(101)\end{array}$ \\
\hline \multirow{3}{*}{$\begin{array}{l}\text { Denitrifying } \\
\text { bacteria }\end{array}$} & nirK & $\begin{array}{c}\mathrm{FlaCu} \\
\mathrm{R} 3 \mathrm{Cu} \\
\text { nirK1F } \\
\text { nirK5R }\end{array}$ & $\begin{array}{c}\text { ATCATGGT(C/G)CTGCCGCG } \\
\text { GCCTCGATCAG(A/G)TTGTGGTT } \\
\text { GG(A/C)ATGGT(G/T)CC(C/G)TGGCA } \\
\text { GCCTCGATCAG(A/G)TT(A/G)TGG } \\
\end{array}$ & 51 & $>400$ & $\begin{array}{c}40-70 \%, 8 \% \\
\text { polyacrylamide }\end{array}$ & $\begin{array}{l}(102) \\
(102) \\
(103) \\
(103)\end{array}$ \\
\hline & nirs & $\begin{array}{l}\text { nirS-1F } \\
\text { nirS6R }\end{array}$ & $\begin{array}{c}\text { CCT A(C/T)T GGC CGC C(A/G)C A(A/G)T } \\
\text { CGTTGAACTT(A/GCCGGT) }\end{array}$ & 55 & 450 & $\begin{array}{c}60-80 \%, 8 \% \\
\text { polyacrylamide }\end{array}$ & $\begin{array}{l}(103) \\
(103) \\
\end{array}$ \\
\hline & nosZ & $\begin{array}{c}\operatorname{nosZ-F} \\
\operatorname{nosZ1622R}\end{array}$ & $\begin{array}{c}\text { CG(C/T)TGTTC(A/C)TCGACAGCCAG } \\
\text { CGC(G/A)A(C/G)GGCAA(G/C)AAGGT(G/C)CG }\end{array}$ & 55 & $>400$ & $\begin{array}{c}60-70 \%, 8 \% \\
\text { polyacrylamide }\end{array}$ & $\begin{array}{c}(104) \\
(64)\end{array}$ \\
\hline
\end{tabular}


The 16S rRNA is not directly used for access the functional groups, however can infer data about the composition of bacterial communities present in many environments ${ }^{124}$, including crops ${ }^{36,125,126}$. Through this, is possible identified all species present in agroecosystems and verified the influence in crop management above which species and the utilization of pesticides ${ }^{9}$, fertilizers ${ }^{127}$, and root exudates ${ }^{35}$. For the16SrRNA gene, Sánchez ${ }^{93}$ compared 6 sets of primers regarding their efficiency in obtaining profiles of bacterioplankton communities (63f and 518r; 357f and 907rM; 357f and 907r; 357f and 518r; 968f and 1401r; 1055f and 1392r) and the best result came from the 357f-GC and 907rM set.

The combinations to amplify nitrifying bacteria isolated from soil samples they were tested. Taking into account the number of amplifications, number of genus, number of environmental samples amplified and the amplicon quality, the set of primers that provided the best result for the NirS gene was cd3aF with R3cd. For the nirK gene, the best results were obtained with the $\mathrm{FlaCu}$ and $\mathrm{R} 3 \mathrm{Cu}$ set. For the nos $\mathrm{Z}$ gene the best combination was nosZ-F with nosZ1622R ${ }^{64}$. There are also, primers based on $16 \mathrm{~S}$ rRNA gene, however, for the identification of target species, as the growth promoters bacteria in plants. Species of Pseudomonas can be accessed through PsF, PsR ${ }^{128}$, F311PS and R1459PS primers ${ }^{129}$. For the genus Burkholderia are cited the BurkR e Burk3 primers ${ }^{130}$.

The set of primers listed on Table 1 for the identification of the $m n o X$ gene was used for archaea characterization from estuaries water ${ }^{131}$. However,used genes such as $16 S r R N A^{132}$ with $27 \mathrm{~F} / 1492 \mathrm{R}$ primers ${ }^{133}$ and the $p m o A$ gene through the a189f/mb661 set ${ }^{97,96}$ to characterize bacterial methanotrophic activities, besides those primers previously cited for archaea.

The access ofthe diversity of microbial species can bring answers more effective about the crop management and soil impact, gas emission, as well as the relation between plants and microorganisms who benefits there development. Some problems as extraction and purification of nucleic acids may be an obstacle for the analysis that depend of PCR. Agricultural environments vary a lot in their chemical composition and there is also the presence of humic acids that is known to inhibits PCR amplification. Even so, the data generate by the utilization of methods from molecular biology, allowed in greater range of results, which do not depend of temperature, oxygen or any other limiting factor of growth, as method of cultivation of microorganisms.

\section{Perspectives}

The DGGE technique can be very promising in agricultural management assessments. The results are fast and have low coast. The cluster analysis of patterns generated by the bands shows the response of the bacterial species, including diversity analysis regarding to the treatment tested. Several Brazilian universities use the technique for various studies. Researchers at UNIOESTE and Unipar evaluated the effects of using wastewater to irrigate crops ${ }^{134}$, comparing the effects of cover crops, evaluated by UFSC ${ }^{135}$, the comparison between different types of management, conducted by UFU ${ }^{136}$ and UNB, Embrapa Cerrado and UFRRJ ${ }^{107}$, comparison of farming systems conducted by UEL, UEM and Embrapa Soja ${ }^{137}$.The UFRJ together with Embrapa Solos and Embrapa Arroz e Feijão, also used the DGGE technique to evaluate treatment using biochar, which provides a reduction in $\mathrm{CO} 2$ emissions by agriculture and the promotion of plants growing ${ }^{138}$. Assessments of ecology and soil dynamics or water in the case of irrigated crops, combine different views on agriculture in search of lower costs to farmers and also, lower environmental impact. 


\section{ACKNOWLEDGEMENT}

This study was funded by fellowships and grants from Rice Irrigated Institute of Rio Grande do Sul (IRGA), Capes (Foundation, Ministry of Education of Brazil) and Microbiology and Toxicology Laboratory Vale do Rio dos Sinos University (UNISINOS).

\section{REFERENCES}

1. Zilli JÉ, Rumjanek NG, Xavier GR, Cristina M, Neves P. DIVERSIDADE MICROBIANA COMO INDICADOR DE QUALIDADE DO SOLO. Cad Cienc Tecnol. 2003;20(3):391-411.

2. Choudhary DK, Sharma KP, Gaur RK. Biotechnological perspectives of microbes in agro-ecosystems. Biotechnol Lett [Internet]. 2011 Oct [cited 2012 Nov 1];33(10):1905-10. Available from: http://www.ncbi.nlm.nih.gov/pubmed/21660571

3. Singh JS, Pandey VC, Singh DP. Efficient soil microorganisms: A new dimension for sustainable agriculture and environmental development. Agric Ecosyst Environ [Internet]. 2011;140(3-4):339-53. Available from: http://dx.doi.org/10.1016/j.agee.2011.01.017

4. Yong X, Cui Y, Chen L, Ran W, Shen Q, Yang X. Dynamics of bacterial communities during solid-state fermentation using agro-industrial wastes to produce poly- $\gamma$-glutamic acid, revealed by real-time PCR and denaturing gradient gel electrophoresis (DGGE). Appl Microbiol Biotechnol [Internet]. 2011 Nov [cited 2012 Dec 20];92(4):717-25. Available from: http://www.ncbi.nlm.nih.gov/pubmed/21670980

5. Mühling M, Woolven-Allen J, Murrell JC, Joint I. Improved group-specific PCR primers for denaturing gradient gel electrophoresis analysis of the genetic diversity of complex microbial communities. ISME J [Internet]. 2008 Apr [cited 2012 Oct 28];2(4):379-92. Available from: http://www.ncbi.nlm.nih.gov/pubmed/18340335

6. Tujula N a, Crocetti GR, Burke C, Thomas T, Holmström C, Kjelleberg S. Variability and abundance of the epiphytic bacterial community associated with a green marine Ulvacean alga. ISME J [Internet]. 2010 Feb [cited 2012 Nov 7];4(2):301-11. Available from: http://www.ncbi.nlm.nih.gov/pubmed/19829319

7. Procópio REL, Araújo WL, Jr WM, Azevedo JL. Characterization of an endophytic bacterial community associated with Eucalyptus spp. 2009;8(4):1408-22.

8. Sun L, Qiu F, Zhang X, Dai X, Dong X, Song W. Endophytic bacterial diversity in rice (Oryza sativa L.) roots estimated by $16 \mathrm{~S}$ rDNA sequence analysis. Microb Ecol [Internet]. 2008 Apr [cited 2012 Oct 30];55(3):415-24. Available from: http://www.ncbi.nlm.nih.gov/pubmed/17690836

9. Barreiros L, Manaia CM, Nunes OC. Bacterial diversity and bioaugmentation in floodwater of a paddy field in the presence of the herbicide molinate. Biodegradation. 2011;22(2):445-61.

10. Prakamhang J, Minamisawa K, Teamtaisong K, Boonkerd N, Teaumroong N. The communities of endophytic diazotrophic bacteria in cultivated rice (Oryza sativa L.). Appl Soil Ecol [Internet]. 2009 Jun [cited 2012 Dec 11];42(2):141-9. Available from: http://linkinghub.elsevier.com/retrieve/pii/S0929139309000511

11. Lu Y, Watanabe A, Kimura M. Contribution of plant-derived carbon to soil microbial biomass dynamics in a paddy rice microcosm. Biol Fertil Soils. 2002;36(2):136-42.

12. Hoque MM, Inubushi K, Miura S, Kobayashi K, Kim HY, Okada M, et al. Biological dinitrogen fixation and soil microbial biomass carbon as influenced by free-air carbon dioxide enrichment (FACE) at three levels of nitrogen fertilization in a paddy field. Biol Fertil Soils. 2001;34(6):453-9.

13. Reichardt W, Briones A, Jesus R De, Padre B. Microbial population shifts in experimental rice systems. 2001;17(January):151-63.

14. Gupta V, Smemo K a, Yavitt JB, Basiliko N. Active methanotrophs in two contrasting North American peatland ecosystems revealed using DNA-SIP. Microb Ecol [Internet]. 2012 Feb [cited 2012 Nov 12];63(2):438-45. Available from: 
http://www.ncbi.nlm.nih.gov/pubmed/21728037

15. Deutzmann JS, Wörner S, Schink B. Activity and diversity of methanotrophic bacteria at methane seeps in eastern Lake Constance sediments. Appl Environ Microbiol [Internet]. 2011 Apr [cited 2012 Nov 23];77(8):2573-81. Available from: http://www.pubmedcentral.nih.gov/articlerender.fcgi?artid=3126381\&tool=pmcentrez\&ren dertype $=$ abstract

16. Tuomivirta TT, Yrjälä K, Fritze H. Quantitative PCR of pmoA using a novel reverse primer correlates with potential methane oxidation in Finnish fen. Res Microbiol [Internet]. Elsevier Masson SAS; 2009 Dec [cited 2012 Nov 30];160(10):751-6. Available from: http://www.ncbi.nlm.nih.gov/pubmed/19781637

17. Griffiths BS, Ritz K, Wheatley RE. Relationship between functional diversity and genetic diversity in complex microbial communities. Microbial communities: functional versus structural approaches. 1997. p. 1-9 ref.

18. Mason NWHH, de Bello F, Mouillot D, Pavoine S, Dray S, Lee WG, et al. Functional richness, functional evenness and functional divergence: The primary components of functional diversity. Oikos [Internet]. 2005;111(1):n/a - n/a. Available from: http://onlinelibrary.wiley.com/doi/10.1111/j.0030-

1299.2005.13886.x/full/nhttp://doi.wiley.com/10.1111/j.0030-

1299.2005.13886.x \nhttp://doi.wiley.com/10.1111/jvs.12013

19. Díaz S, Lavorel S, de Bello F, Quétier F, Grigulis K, Robson TM. Incorporating plant functional diversity effects in ecosystem service assessments. Proc Natl Acad Sci U S A. 2007;104:20684-9.

20. Mouchet MA, Villéger S, Mason NWH, Mouillot D. Functional diversity measures: An overview of their redundancy and their ability to discriminate community assembly rules. Funct Ecol. 2010;24(4):867-76.

21. Naeem S, Thompson LJ, Lawler SP, Lawton JH, Woodfin RM. Empirical Evidence that Declining Species Diversity May Alter the Performance of Terrestrial Ecosystems. Philosophical Transactions of the Royal Society B: Biological Sciences. 1995. p. 249-62.

22. Tilman D, Wedin D, Knops J. Productivity and sustainability influenced by biodiversity in grassland ecosystems. Nature. 1996. p. 718-20.

23. Müller a K, Westergaard K, Christensen S, Sørensen SJ. The diversity and function of soil microbial communities exposed to different disturbances. Microb Ecol [Internet]. 2002 Jul;44(1):49-58. Available from: http://www.ncbi.nlm.nih.gov/pubmed/11976785

24. Tilman D, Knops J, Wedin D, Reich P, Ritchie M, Siemann E. The influence of functional diversity and composition on ecosystem processes. Science (80- ) [Internet]. 1997;277:1300-2. Available from: <Go to ISI>://A1997XT82700053

25. Hooper DU, Vitousek PM. The effects of plant composition and diversity on ecosystem processes. Sci (washingt D C). 1997;277:1302-5.

26. Wardle DA. The Influence of Island Area on Ecosystem Properties. Science. 1997. p. 1296-9.

27. Franklin RB, Mills AL. Structural and functional responses of a sewage microbial community to dilution-induced reductions in diversity. Microb Ecol [Internet]. 2006 Aug [cited 2012 Dec 4];52(2):280-8. Available from: http://www.ncbi.nlm.nih.gov/pubmed/16897310

28. Liu G, Xie X, Ye D, Ye X, Tuvshintogtokh I, Mandakh B, et al. Plant Functional Diversity and Species Diversity in the Mongolian Steppe. PLoS One. 2013;8(10):1-9.

29. Katovai E, Burley AL, Mayfield MM. Understory plant species and functional diversity in the degraded wet tropical forests of Kolombangara Island, Solomon Islands. Biol Conserv [Internet]. 2012;145(1):214-24. Available from: http://dx.doi.org/10.1016/j.biocon.2011.11.008

30. Schuldt A, Bruelheide H, Durka W, Michalski SG, Purschke O, Assmann T. Tree diversity promotes functional dissimilarity and maintains functional richness despite species loss in predator assemblages. Oecologia [Internet]. 2014;174(2):533-43. Available from: http://www.ncbi.nlm.nih.gov/pubmed/24096740

31. Boulay JN, Hellberg ME, Cortés J, Baums IB. Unrecognized coral species diversity masks differences in functional ecology. Proc R Soc B Biol Sci. 2014;281:20131580.

32. Ferrer M, Guazzaroni M-E, Richter M, García-Salamanca A, Yarza P, Suárez-Suárez A, et al. Taxonomic and functional metagenomic profiling of the microbial community in the 
anoxic sediment of a sub-saline shallow lake (Laguna de Carrizo, Central Spain). Microb Ecol [Internet]. 2011 Nov [cited 2012 Nov 2];62(4):824-37. Available from: http://www.ncbi.nlm.nih.gov/pubmed/21735153

33. Belila A, Snoussi M, Hassan A. Rapid qualitative characterization of bacterial community in eutrophicated wastewater stabilization plant by T-RFLP method based on 16S rRNA genes. World J Microbiol Biotechnol [Internet]. 2012 Jan [cited 2012 Dec 20];28(1):13543. Available from: http://www.ncbi.nlm.nih.gov/pubmed/22806789

34. Hérault B. Reconciling niche and neutrality through the Emergent Group approach. Perspect Plant Ecol Evol Syst. 2007;9(2):71-8.

35. Andreote FD, Azevedo JL, Araújo WL. Assessing the diversity of bacterial communities associated with plants. Braz J Microbiol [Internet]. 2009;40:417-32. Available from: http://www.pubmedcentral.nih.gov/articlerender.fcgi?artid=3768544\&tool=pmcentrez\&ren dertype $=$ abstract

36. Asakawa S, Kimura M. Comparison of bacterial community structures at main habitats in paddy field ecosystem based on DGGE analysis. Soil Biol Biochem [Internet]. 2008 Jun [cited 2012 Dec 16];40(6):1322-9. Available from: http://linkinghub.elsevier.com/retrieve/pii/S0038071707003914

37. Wang MC, Liu YH, Wang Q, Gong M, Hua XM, Pang YJ, et al. Impacts of methamidophos on the biochemical, catabolic, and genetic characteristics of soil microbial communities. Soil Biol Biochem. 2008;40(3):778-88.

38. Johnsen K, Jacobsen CS, Torsvik V, Sorensen J. Pesticide effects on bacterial diversity in agricultural soils - a review. Biol Fertil Soils [Internet]. 2001;33(6):443-53. Available from: <GolntolnISI >://000170021900001

39. Joynt J, Bischoff M, Turco R, Konopka A, Nakatsu CH. Microbial community analysis of soils contaminated with lead, chromium and petroleum hydrocarbons. Microb Ecol. 2006;51(2):209-19.

40. Futamata H, Sakai M, Ozawa H, Urashima Y, Sueguchi T, Matsuguchi T. Chemotactic response to amino acids of fluorescent pseudomonads isolated from spinach roots grown in soils with different salinity levels. Soil Science and Plant Nutrition. 1998. p. 1-7.

41. Gao Y, Yu XZ, Wu SC, Cheung KC, Tam NFY, Qian PY, et al. Interactions of rice (Oryza sativa L.) and PAH-degrading bacteria (Acinetobacter sp.) on enhanced dissipation of spiked phenanthrene and pyrene in waterlogged soil. Sci Total Environ. 2006;372(1):111.

42. Yin B, Crowley D, Sparovek G, De Melo WJ, Borneman J. Bacterial functional redundancy along a soil reclamation gradient. Appl Environ Microbiol. 2000;66(10):43615 .

43. Chapin III FS, Walker BH, Hobbs RJ, Hooper DU, Lawton JH, Sala OE, et al. Biotic control over the functioning of ecosystems. Science (80- ) [Internet]. 1997;277(5325):500. Available from: http://www.sciencemag.org/cgi/content/abstract/277/5325/500

44. Cowan D, Meyer Q, Stafford W, Muyanga S, Cameron R, Wittwer P. Metagenomic gene discovery: Past, present and future. Trends in Biotechnology. 2005. p. 321-9.

45. Farjalla V, Esteves F, Bozelli R, Roland F. Nutrient limitation of bacterial production in clear water Amazonian ecosystems. Hydrobiologia [Internet]. 2002 [cited 2014 Dec 1];(1990):197-205. Available http://link.springer.com/article/10.1023/A:1023288922394

46. Uchiyama $\mathrm{T}$, Abe $\mathrm{T}$, Ikemura $\mathrm{T}$, Watanabe K. Substrate-induced gene-expression screening of environmental metagenome libraries for isolation of catabolic genes. Nat Biotechnol. 2005;23:88-93.

47. Ercolini D. PCR-DGGE fingerprinting: Novel strategies for detection of microbes in food. Journal of Microbiological Methods. 2004. p. 297-314.

48. Zhong Y, Wang J, Song Y, Liang Y, Li G. Microbial community and functional genes in the rhizosphere of alfalfa in crude oil-contaminated soil. Front Environ Sci Eng China. 2012;6:797-805.

49. Srinandan CS, Shah M, Patel B, Nerurkar AS. Assessment of denitrifying bacterial composition in activated sludge. Bioresour Technol. 2011;102:9481-9.

50. Maron P-A, Ranjard L, Mougel C, Lemanceau P. Metaproteomics: a new approach for studying functional microbial ecology. Microb Ecol [Internet]. 2007 Apr [cited 2012 Oct 30];53(3):486-93. Available from: http://www.ncbi.nlm.nih.gov/pubmed/17431707 
51. Fisher MM, Triplett EW. Automated approach for ribosomal intergenic spacer analysis of microbial diversity and its application to freshwater bacterial communities. Appl Environ Microbiol. 1999;65:4630-6.

52. Muyzer G, De Waal EC, Uitterlinden AG. Profiling of complex microbial populations by denaturing gradient gel electrophoresis analysis of polymerase chain reaction-amplified genes coding for 16S rRNA. Appl Environ Microbiol. 1993;59:695-700.

53. Muyzer G, Smalla K. Application of denaturing gradient gel electrophoresis (DGGE) and temperature gradient gel electrophoresis (TGGE) in microbial ecology. Antonie Van Leeuwenhoek [Internet]. 1998 Jan;73(1):127-41. Available from: http://www.ncbi.nlm.nih.gov/pubmed/9602286

54. McGarvey JA, Miller WG, Sanchez S, Stanker L. Identification of bacterial populations in dairy wastewaters by use of $16 \mathrm{~S}$ rRNA gene sequences and other genetic markers. Appl Environ Microbiol. 2004;70:4267-75.

55. Otawa K, Asano R, Ohba Y, Sasaki T, Kawamura E, Koyama F, et al. Molecular analysis of ammonia-oxidizing bacteria community in intermittent aeration sequencing batch reactors used for animal wastewater treatment. Environ Microbiol. 2006;8:1985-96.

56. Lefebvre O, Ha Nguyen TT, Al-Mamun A, Chang IS, Ng HY. T-RFLP reveals high Proteobacteria diversity in microbial fuel cells enriched with domestic wastewater. J Appl Microbiol. 2010;109:839-50.

57. Smalla K, Oros-Sichler M, Milling A, Heuer H, Baumgarte S, Becker R, et al. Bacterial diversity of soils assessed by DGGE, T-RFLP and SSCP fingerprints of PCR-amplified 16S rRNA gene fragments: Do the different methods provide similar results? J Microbiol Methods. 2007;69:470-9.

58. Scully C, Collins G, O'Flaherty V. Assessment of anaerobic wastewater treatment failure using terminal restriction fragment length polymorphism analysis. J Appl Microbiol. 2005;99:1463-71.

59. Mbwana J, Bolin I, Lyamuya E, Mhalu F, Lagergard T. Molecular characterization of Haemophilus ducreyi isolates from different geographical locations. J Clin Microbiol [Internet]. 2006;44:132-7. Available from: http://www.ncbi.nlm.nih.gov/entrez/query.fcgi? $\mathrm{cmd}=$ Retrieve $\& \mathrm{db}=$ PubMed\&dopt=Citatio n\&list_uids $=16390960$

60. Kubo KS, Stuart RM, Freitas-Astúa J, Antonioli-Luizon R, Locali-Fabris EC, ColettaFilho HD, et al. Evaluation of the genetic variability of orchid fleck virus by single-strand conformational polymorphism analysis and nucleotide sequencing of a fragment from the nucleocapsid gene. Arch Virol. 2009;154:1009-14.

61. Trevors JT, Masson L. DNA technologies: What's next applied to microbiology research? Antonie van Leeuwenhoek, International Journal of General and Molecular Microbiology. 2010. p. 249-62.

62. McDonald IR, Bodrossy L, Chen Y, Murrell JC. Molecular ecology techniques for the study of aerobic methanotrophs. Appl Environ Microbiol [Internet]. 2008 Mar [cited 2012 Nov 2];74(5):1305-15. Available from: http://www.pubmedcentral.nih.gov/articlerender.fcgi?artid=2258629\&tool=pmcentrez\&ren dertype $=$ abstract

63. Dar SA, Yao L, Van Dongen U, Kuenen JG, Muyzer G. Analysis of diversity and activity of sulfate-reducing bacterial communities in sulfidogenic bioreactors using 16S rRNA and dsrB genes as molecular markers. Appl Environ Microbiol. 2007;73:594-604.

64. Throbäck IN, Enwall K, Jarvis A, Hallin S. Reassessing PCR primers targeting nirS, nirK and nosZ genes for community surveys of denitrifying bacteria with DGGE. FEMS Microbiol Ecol [Internet]. 2004 Sep 1 [cited 2014 Oct 15];49(3):401-17. Available from: http://www.ncbi.nlm.nih.gov/pubmed/19712290

65. Wertz S, Dandie CE, Goyer C, Trevors JT, Patten CL. Diversity of nirK denitrifying genes and transcripts in an agricultural soil. Appl Environ Microbiol [Internet]. 2009 Dec [cited 2014 Oct 22];75(23):7365-77. Available from: http://www.pubmedcentral.nih.gov/articlerender.fcgi?artid=2786405\&tool=pmcentrez\&ren dertype $=$ abstract

66. Möhlenhoff P, Müller L, Gorbushina AA, Petersen K. Molecular approach to the characterisation of fungal communities: Methods for DNA extraction, PCR amplification and DGGE analysis of painted art objects. FEMS Microbiol Lett. 2001;195:169-73. 
67. Temmerman R, Scheirlinck I, Huys G, Swings J. Culture-independent analysis of probiotic products by denaturing gradient gel electrophoresis. Appl Environ Microbiol. 2003;69:220-6.

68. Hill P, Krištůfek V, Dijkhuizen L, Boddy C, Kroetsch D, van Elsas JD. Land use intensity controls actinobacterial community structure. Microb Ecol [Internet]. 2011 Feb [cited 2012 Dec 20];61(2):286-302. Available from: http://www.pubmedcentral.nih.gov/articlerender.fcgi?artid=3232471\&tool=pmcentrez\&ren dertype $=$ abstract

69. Lemos LN, Fulthorpe RR, Roesch LFW. Low sequencing efforts bias analyses of shared taxa in microbial communities. Folia Microbiol (Praha) [Internet]. 2012 Sep [cited 2012 Nov 7];57(5):409-13. Available from: http://www.ncbi.nlm.nih.gov/pubmed/22562492

70. Dini-Andreote F, Andreote FD, Araújo WL, Trevors JT, van Elsas JD. Bacterial genomes: habitat specificity and uncharted organisms. Microb Ecol [Internet]. 2012 Jul [cited 2012 Nov 11];64(1):1-7. Available from: http://www.pubmedcentral.nih.gov/articlerender.fcgi?artid=3375415\&tool=pmcentrez\&ren dertype $=$ abstract

71. Lüke C, Frenzel P. Potential of pmoA amplicon pyrosequencing for methanotroph diversity studies. Appl Environ Microbiol [Internet]. 2011 Sep [cited 2012 Nov 9];77(17):6305-9. Available from: http://www.pubmedcentral.nih.gov/articlerender.fcgi?artid=3165393\&tool=pmcentrez\&ren dertype $=$ abstract

72. Edwards RA, Rodriguez-Brito B, Wegley L, Haynes M, Breitbart M, Peterson DM, et al. Using pyrosequencing to shed light on deep mine microbial ecology. BMC Genomics. 2006;7:57.

73. Shendure J, Ji H. Next-generation DNA se1. Shendure J, Ji H. Next-generation DNA sequencing. Nat Biotechnol. 2008;26(10):1135-45. quencing. Nat Biotechnol. 2008;26(10):1135-45.

74. Huse SM, Welch DM, Morrison HG, Sogin ML. Ironing out the wrinkles in the rare biosphere through improved OTU clustering. Environ Microbiol. 2010;12(7):1889-98.

75. Quince C, Lanzén A, Curtis TP, Davenport RJ, Hall N, Head IM, et al. Accurate determination of microbial diversity from 454 pyrosequencing data. Nat Methods. 2009;6:639-41.

76. Kondo HM, Pressnitzer D, Toshima I, Kashino M. ROTHBERG: Effects of self-motion on auditory scene analysis. Proc Natl Acad Sci U S A [Internet]. 2012;109(17):6775-80. Available from: http://www.ncbi.nlm.nih.gov/pubmed/22493250

77. Salipante SJ, Sengupta DJ, Rosenthal C, Costa G, Spangler J, Sims EH, et al. Rapid 16S rRNA Next-Generation Sequencing of Polymicrobial Clinical Samples for Diagnosis of Complex Bacterial Infections. PLoS One. 2013;8(5).

78. He Z, Gentry TJ, Schadt CW, Wu L, Liebich J, Chong SC, et al. GeoChip: a comprehensive microarray for investigating biogeochemical, ecological and environmental processes. ISME J. 2007;1(1):67-77.

79. Hättenschwiler S, Fromin N, Barantal S. Functional diversity of terrestrial microbial decomposers and their substrates. Comptes Rendus - Biologies. 2011. p. 393-402.

80. Dickens HE, Anderson JM. Manipulation of soil microbial community structure in bog and forest soils using chloroform fumigation. Soil Biol Biochem. 1999;31:2049-58.

81. McDonald IR, Bodrossy L, Chen Y, Murrell JC. Molecular ecology techniques for the study of aerobic methanotrophs. Appl Environ Microbiol. 2008;74(5):1305-15.

82. Jaatinen K, Tuittila E-S, Laine J, Yrjälä K, Fritze H. Methane-oxidizing bacteria in a Finnish raised mire complex: effects of site fertility and drainage. Microb Ecol. 2005;50:429-39.

83. Reimann J, Jetten MSM, Keltjens JT. Metal Enzymes in "Impossible" Microorganisms Catalyzing the Anaerobic Oxidation of Ammonium and Methane. 2015. p. 257-313. Available from: http://link.springer.com/10.1007/978-3-319-12415-5_7

84. Chu H, Fujii T, Morimoto S, Lin X, Yagi K, Hu J, et al. Community Structure of Ammonia-Oxidizing Bacteria under Long-Term Application of Mineral Fertilizer and Organic Manure in a Sandy Loam Soil. Appl Environ Microbiol [Internet]. 2007 Jan 1;73(2):485-91. Available from: http://aem.asm.org/cgi/doi/10.1128/AEM.01536-06

85. Kowalchuk GA, Stephen JR. Ammonia-oxidizing bacteria: A model for molecular 
microbial ecology. Annu Rev Microbiol [Internet]. 2001;55:485-529. Available from: <Go to

ISI $>$ ://WOS:000171732600020ไnhttp://apps.webofknowledge.com/full_record.do?product= UA\&search_mode=GeneralSearch\&qid $=14 \& S I D=Y 2 u O 2 W v x M u w q r j M R d p M \& p a g e=1 \&$ doc $=4$

86. Bernhard AE, Landry ZC, Blevins A, de la Torre JR, Giblin AE, Stahl D a. Abundance of ammonia-oxidizing archaea and bacteria along an estuarine salinity gradient in relation to potential nitrification rates. Appl Environ Microbiol [Internet]. 2010 Feb [cited 2012 Dec 13];76(4):1285-9. Available from: http://www.pubmedcentral.nih.gov/articlerender.fcgi?artid=2820943\&tool=pmcentrez\&ren dertype=abstract

87. Reed DW, Smith JM, Francis C a, Fujita Y. Responses of ammonia-oxidizing bacterial and archaeal populations to organic nitrogen amendments in low-nutrient groundwater. Appl Environ Microbiol [Internet]. 2010 Apr [cited 2012 Nov 12];76(8):2517-23. Available

from: http://www.pubmedcentral.nih.gov/articlerender.fcgi?artid=2849197\&tool=pmcentrez\&ren dertype $=$ abstract

88. Borneman J, Skroch PW, O’Sullivan KM, Palus JA, Rumjanek NG, Jansen JL, et al. Molecular microbial diversity of an agricultural soil in Wisconsin. Appl Environ Microbiol. 1996;62:1935-43.

89. Tan Z, Hurek T, Reinhold-Hurek B. Effect of N-fertilization, plant genotype and environmental conditions on nifH gene pools in roots of rice. Environ Microbiol. 2003;5:1009-15.

90. Priemé A, Braker G, Tiedje JM. Diversity of nitrite reductase (nirK and nirS) gene fragments in forested upland and wetland soils. Appl Environ Microbiol. 2002;68:1893900.

91. Jayakumar DA, Francis CA, Naqvi SWA, Ward BB. Diversity of nitrite reductase genes $(n i r S)$ in the denitrifying water column of the coastal Arabian Sea. Aquat Microb Ecol [Internet]. 2004;34:69-78. Available from: http://www.intres.com/abstracts/ame/v34/n1/p69-78/

92. Scala DJ, Kerkhof LJ. Horizontal heterogeneity of denitrifying bacterial communities in marine sediments by terminal restriction fragment length polymorphism analysis. Appl Environ Microbiol. 2000;66:1980-6.

93. Sánchez O, Gasol JM, Massana R, Mas J, Pedrós-Alió C. Comparison of different denaturing gradient gel electrophoresis primer sets for the study of marine bacterioplankton communities. Appl Environ Microbiol. 2007;73:5962-7.

94. Nikolausz M, Sipos R, Révész S, Székely A, Márialigeti K. Observation of bias associated with re-amplification of DNA isolated from denaturing gradient gels. FEMS Microbiol Lett. 2005;244(2):385-90.

95. Holmes AJ, Costello A, Lidstrom ME, Murrell JC. Evidence that particulate methane monooxygenase and ammonia monooxygenase may be evolutionarily related. 1995; 132:203-8.

96. Costello AM, Lidstrom ME. Molecular characterization of functional and phylogenetic genes from natural populations of methanotrophs in lake sediments. Appl Environ Microbiol. 1999;65:5066-74.

97. Bourne D. Comparison of pmoA PCR primer sets as tools for investigating methanotroph diversity in three Danish soils. Appl Environ ... [Internet]. 2001 [cited 2014 Dec 1];67(9):3802-9. Available from: http://aem.asm.org/content/67/9/3802.short

98. Hutchens E, Radajewski S, Dumont MG, McDonald IR, Murrell JC. Analysis of methanotrophic bacteria in Movile Cave by stable isotope probing. Environ Microbiol. 2004;6(2):111-20.

99. Rotthauwe JH, Witzel KP, Liesack W. The ammonia monooxygenase structural gene amoA as a functional marker: molecular fine-scale analysis of natural ammonia-oxidizing populations. Appl Environ Microbiol [Internet]. 1997 Dec;63(12):4704-12. Available from:

http://www.pubmedcentral.nih.gov/articlerender.fcgi?artid=168793\&tool=pmcentrez\&rend ertype $=$ abstract

100. Simonet P, Grosjean MC, Misra AK, Nazaret S, Cournoyer B, Normand P. 
Frankia genus-specific characterization by polymerase chain reaction. Appl Environ Microbiol. 1991;57(11):3278-86.

101. Poly F, Monrozier LJ, Bally R. Improvement in the RFLP procedure for studying the diversity of nifH genes in communities of nitrogen fixers in soil. Res Microbiol. 2001;152(1):95-103.

102. Liu X, Tiquia SM, Holguin G, Wu L, Nold SC, Devol AH, et al. Molecular Diversity of Denitrifying Genes in Continental Margin Sediments within the OxygenDeficient Zone off the Pacific Coast of Mexico Molecular Diversity of Denitrifying Genes in Continental Margin Sediments within the Oxygen-Deficient Zone off the P. 2003;

103. Braker G, Fesefeldt A, Witzel K. Development of PCR Primer Systems for Amplification of Nitrite Reductase Genes ( nirK and nirS ) To Detect Denitrifying Bacteria in Environmental Samples Development of PCR Primer Systems for Amplification of Nitrite Reductase Genes ( nirK and nirS ) To D. 1998;

104. Kloos K, Mergel A, Rösch C, Bothe H. Denitrification within the genus Azospirillum and other associative bacteria. Aust J Plant Physiol. 2001;28(8):991-8.

105. Phongpan S, Mosier AR. Effect of crop residue management on nitrogen dynamics and balance in a lowland rice cropping system. Nutr Cycl Agroecosystems [Internet]. 2003;66(2):133-42. Available from: http://www.scopus.com/inward/record.url?eid=2-s2.0-0038719642\&partnerID=tZOtx3y1

106. De Datta SK, Buresh RJ. Integrated Nitrogen Management in Irrigated Rice. Advances in Soil Science [Internet]. 1989. p. 143-69. Available from: http://link.springer.com/chapter/10.1007\%2F978-1-4613-8847-0_4

107. dos Santos a CF, Marques ELS, Gross E, Souza SS, Dias JCT, Brendel M, et al. Detection by denaturing gradient gel electrophoresis of ammonia-oxidizing bacteria in microcosms of crude oil-contaminated mangrove sediments. Genet Mol Res [Internet]. 2012 Jan;11(1):190-201. Available from: http://www.ncbi.nlm.nih.gov/pubmed/22370886

108. Bruns MA, Fries MR, Tiedje JM, Paul EA. Functional gene hybridization patterns of terrestrial ammonia-oxidizing bacteria. Microb Ecol. 1998;36:293-302.

109. Hoppert M, Mahony T, Mayer F, Miller D. Quaternary structure of the hydroxylamine oxidoreductase from Nitrosomonas europaea. Arch Microbiol [Internet]. 1995 [cited 2014 Dec 2];300-6. Available from: http://link.springer.com/article/10.1007/BF00393384

110. Arciero DM, Hooper AB. Hydroxylamine oxidoreductase from Nitrosomonas europaea is a multimer of an octa-heme subunit. J Biol Chem. 1993;268(20):14645-54.

111. Bergmann DJ, Arciero DM, Hooper AB. Organization of the hao gene cluster of Nitrosomonas europaea: Genes for two tetraheme c cytochromes. $J$ Bacteriol. 1994;176:3148-53.

112. Sayavedrasoto LA, Hommes NG, Arp DJ. Characterization of the gene encoding hydroxylamine oxidoreductase in nitrosomonas-europaea. J Bacteriol. 1994;176:504-10.

113. Murrell JC. The Aerobic Methane Oxidizing Bacteria (Methanotrophs). Handbook of Hydrocarbon and Lipid Microbiology [Internet]. 2010. p. 1953-66. Available from: http://link.springer.com/10.1007/978-3-540-77587-4

114. Knittel K, Boetius A. Anaerobic oxidation of methane: progress with an unknown process. Annu Rev Microbiol. 2009;63:311-34.

115. Zhu B, van Dijk G, Fritz C, Smolders AJP, Pol A, Jetten MSM, et al. Anaerobic oxidization of methane in a minerotrophic peatland: Enrichment of nitrite-dependent methane-oxidizing bacteria. Appl Environ Microbiol. 2012;78(24):8657-65.

116. Orphan VJ, Hinrichs KU, Iii WU, Paull CK, Taylor LT, Sylva SP, et al. Comparative analysis of methane-oxidizing archaea and sulfate-reducing bacteria in anoxic marine sediments. Appl Environ Microbiol. 2001;67(4):1922-34.

117. Dumont MG, Murrell JC. Community-level analysis: Key genes of aerobic methane oxidation. Methods Enzymol. 2005;397:413-27.

118. Degelmann DM, Borken W, Drake HL, Kolb S. Different atmospheric methaneoxidizing communities in european beech and norway spruce soils. Appl Environ Microbiol. 2010;76:3228-35.

119. Henckel T, Jäckel U, Schnell S, Conrad R. Molecular analyses of novel methanotrophic communities in forest soil that oxidize atmospheric methane. Appl Environ Microbiol. 2000;66:1801-8. 
120. Jensen S, Holmes AJ, Olsen RA, Murrell JC. Detection of Methane Oxidizing Bacteria in Forest Soil by. 2000;282-9.

121. McDonald IR, Upton M, Hall G, Pickup RW, Edwards C, Saunders JR, et al. Molecular ecological analysis of methanogens and methanotrophs in blanket bog peat. Microb Ecol. 1999;38:225-33.

122. Roesch LFW, Olivares FL, Pereira Passaglia LM, Selbach PA, De Sá ELS, De Camargo FAO. Characterization of diazotrophic bacteria associated with maize: Effect of plant genotype, ontogeny and nitrogen-supply. World J Microbiol Biotechnol. 2006;22:967-74.

123. Dedysh SN, Ricke P, Liesack W. NifH and NifD phylogenies: An evolutionary basis for understanding nitrogen fixation capabilities of methanotrophic bacteria. Microbiology. 2004;150:1301-13.

124. Buse HY, Lu J, Lu X, Mou X, Ashbolt NJ. Microbial diversities (16S and 18S rRNA gene pyrosequencing) and environmental pathogens within drinking water biofilms grown on the common premise plumbing materials unplasticized polyvinylchloride and copper. FEMS Microbiol Ecol [Internet]. 2014 May [cited 2014 Dec 1];88(2):280-95. Available from: http://www.ncbi.nlm.nih.gov/pubmed/24490699

125. Souza RC, Cantão ME, Vasconcelos ATR, Nogueira MA, Hungria M. Soil metagenomics reveals differences under conventional and no-tillage with crop rotation or succession. Appl Soil Ecol [Internet]. 2013;72:49-61. Available from: http://dx.doi.org/10.1016/j.apsoil.2013.05.021

126. Souza R, Beneduzi A, Ambrosini A, Costa PB, Meyer J, Vargas LK, et al. The effect of plant growth-promoting rhizobacteria on the growth of rice (Oryza sativa L.) cropped in southern Brazilian fields. Plant Soil [Internet]. 2012 Sep 21 [cited 2012 Dec 20];32. Available from: http://www.springerlink.com/index/10.1007/s11104-012-1430-1

127. Shibagaki-Shimizu T, Nakayama N, Nakajima Y, Matsuya K, Kimura M, Asakawa S. Phylogenetic study on a bacterial community in the floodwater of a Japanese paddy field estimated by sequencing $16 \mathrm{~S}$ rDNA fragments after denaturing gradient gel electrophoresis. Biol Fertil Soils [Internet]. 2006 Mar 9;42(4):362-5. Available from: http://link.springer.com/10.1007/s00374-005-0041-x

128. Garbeva P, Van Veen JA, Van Elsas JD. Assessment of the diversity, and antagonism towards Rhizoctonia solani AG3, of Pseudomonas species in soil from different agricultural regimes. FEMS Microbiol Ecol. 2004;47(1):51-64.

129. Milling A, Smalla K, Maidl FX, Schloter M, Munch JC. Effects of transgenic potatoes with an altered starch composition on the diversity of soil and rhizosphere bacteria and fungi. Plant Soil [Internet]. 2004;266(1-2):23-39. Available from: <Go to ISI>://WOS:000226385500004lnhttp://download.springer.com/static/pdf/526/art\%253A10. $1007 \% 252 \mathrm{Fs} 11104-005-4906-$ 4.pdf?auth66=1386420337_051b22b1fda02dc9d791a827b2459401\&ext=.pdf

130. Salles JF, De Souza FA, Van Elsas JD. Molecular Method To Assess the Diversity of Burkholderia Species in Environmental Samples. Appl Environ Microbiol [Internet]. 2002;68:1595-603. Available from: http://aem.asm.org/cgi/content/abstract/68/4/1595

131. Cunliffe M, Schafer H, Harrison E, Cleave S, Upstill-Goddard R, Murrell JC. Phylogenetic and functional gene analysis of the bacterial and archaeal communities associated with the surface microlayer of an estuary. ISME J [Internet]. 2008;2(7):776-89. Available from: http://dx.doi.org/10.1038/ismej.2008.28

132. Chen Y, Dumont MG, Cébron A, Murrell JC. Identification of active methanotrophs in a landfill cover soil through detection of expression of 16S rRNA and functional genes. Environ Microbiol. 2007;9:2855-69.

133. Lane DJ. 16S/23S rRNA sequencing. Nucleic Acid Techniques in Bacterial Systematics [Internet]. 1991. p. 115-75. Available from: http://ci.nii.ac.jp/naid/10018533690/en/

134. Moura AC de, Sampaio SC, Remor MB, Silva AP da, Pereira P.Long- term effects of swine wastewater and mineral fertilizer association on soil microbiota. J Brazilian Assoc Agric Eng. 2016;36(2):318-28.

135. Heberle E dos S, Armas RD de, Heberle DA, Sturmer SL, Peruch LAM, Lovato $\mathrm{PE}$, et al. Occurrence and structure of arbuscular mycorrhizal fungal communities in 
cassava after cultivation of cover crops as observed by the "PCR-DGGE" technique. Rev Bras Cienc do Solo [Internet]. 2015;39(5):1292-301. Available from: http://dx.doi.org/10.1590/01000683rbcs20140216

136. Azevedo LCB, Morais M, Lambais MR. Early changes in soil metabolic diversity and bacterial community structure in sugarcane under two harvest management systems. Rev Bras Cienc Do Solo [Internet]. 2015;39(3):701-13. Available from: <Go to ISI>://WOS:000359314500007

137. Babujia LC, Silva AP, Nogueira MA, Hungria M. Microbial diversity in an Oxisol under no-tillage and conventional tillage in southern Brazil. Rev Cienc Agron. 2014;45(5):863-70.

138. Leite DCA, Balieiro FC, Pires CA, Madari BE, Rosado AS, Coutinho HLC, et al. Comparison of DNA extraction protocols for microbial communities from soil treated with biochar. Brazilian J Microbiol. 2014;45(1):175-83.

Received: February 03, 2016; Accepted: July 14, 2016 